\title{
街区内における建物群の津波耐力評価に関する 模型実験
}

\author{
小笠原 敏記 1 三橋 寛 2 - 室井 宏太 3 - 水野 辰哉 3 \\ 1正会員 岩手大学准教授 理工学部システム創成工学科（†020-8551 岩手県盛岡市上田四丁目3-5） \\ E-mail:togasa@iwate-u.ac.jp \\ 2 日本地下水開発株式会社（ \\ 3学生会員 岩手大学大学院 工学研究科社会環境工学専攻（广020-8551 岩手県盛岡市上田四丁目3-5)
}

\begin{abstract}
東日本大震災では, 隣接する建物でも被災規模が異なることが確認されているため, 建物群における各 建物の津波耐力評価が必要と考えられる。街区を想定した建物群を3Dプリンターで再現した模型実験を 基に, 津波氾濫流の波圧を明らかにする。ささらに, 各建物の必要津波耐力について, 建物面積および建 物形状を指標とした評価方法を検討する。 その結果, 海側の前方に建物が存在するような後方の建物に おいて, 波圧は著しく減少するだけでなく, 入射波の増大に関わらず小さくなることがわかった。さら に, 建物の津波耐力評価として, 建物面積率および建物円形度の指標を提案し, 建物倒壊の危険性を判 断する指標になり得ることを示唆した.
\end{abstract}

Key Words : tsunami force, building group, block scale, model experiment

\section{1. 序論}

2011年東北地方太平洋沖地震に伴う津波では，国土交 通省都市局点が実施した東日本大震災による建物被災調 査データを基に，岩手県沿岸の建物の被災状況の特性を 明らかにしてきた2). その結果から, 数百メートル規模 の街区内で隣接する建物であっても，各建物の被災規模 が異なることが確認されている，そのため，津波に強い まちづくりを考える上で，単一建物の耐力評価に限らず, 街区規模の面的な建物群としての各建物の必要津波耐力 の評価が重要と言える.

これまでの既往研究では，単一建物に対する耐力評価， すなわち，建物に及ぼす津波による外力荷重について， 様々な検討が行われている. Asakura et al. . $^{3}$ は，陸上構造 物に作用する津波波力をフルード数に依存した水平波圧 指標で評価できることを提案している. 有光ら ${ }^{4}$ は, 形 状の異なる構造物に作用する津波波圧を構造物前面の浸 水深および水平方向流速を用いて評価している. さらに， 有川・大塚5は，異なる形状の各構造物を横断方向に規 則的に配置した実験を行い，各構造物に対する津波の作 用力の検討を行っている.

しかしながら, 街区規模における隣接した建物群に作 用する津波汇濫の波圧特性の把握は未解明のままと言え る. そのため, 建物群における各建物の津波耐力の評価 が必要と考えられる.
そこで本研究では, 街区の建物群を3Dプリンターで 正確に再現した模型実験を基に，各建物に作用する津波 汇濫流の波圧を明らかにする，さらに，街区における各 建物の必要津波耐力の評価方法について, 建物群の面積 または形状を指標とした検討を行う。

\section{2. 実験の概要}

ここでは，街区を想定した建物群の選定方法および建 物群模型の製作過程を述べる.ささらに，その模型を用い た水理実験について, 各実験装置, 計測方法および実験 条件を示寸.

\section{（1）街区における建物群の選定方法}

実験に用いるための街区を想定した建物群の選定には, 比較的平らな地形で約 $100 \mathrm{~m}$ 四方に複数の建物が存在す ること，それぞれの建物の被災状況1が明らかであり， 被災状況の規模が異なることを条件とする．また，街区 内に浸水高の記録功あることも考慮する.

東日本大震災では, 岩手県の沿岸12市町村で23072戸 の建物が被害を受け, 陸前高田市を始め, 多くの地域で 流失や全壊のような壊滅的な被害を受けている2゙，その ため，建物の被災規模にバラつきがあり，平野部の地域 は限定される. 写真-1は, 震災前の岩手県久慈市の様子 である．市街地の地形は，長内川と合流した久慈川が久 


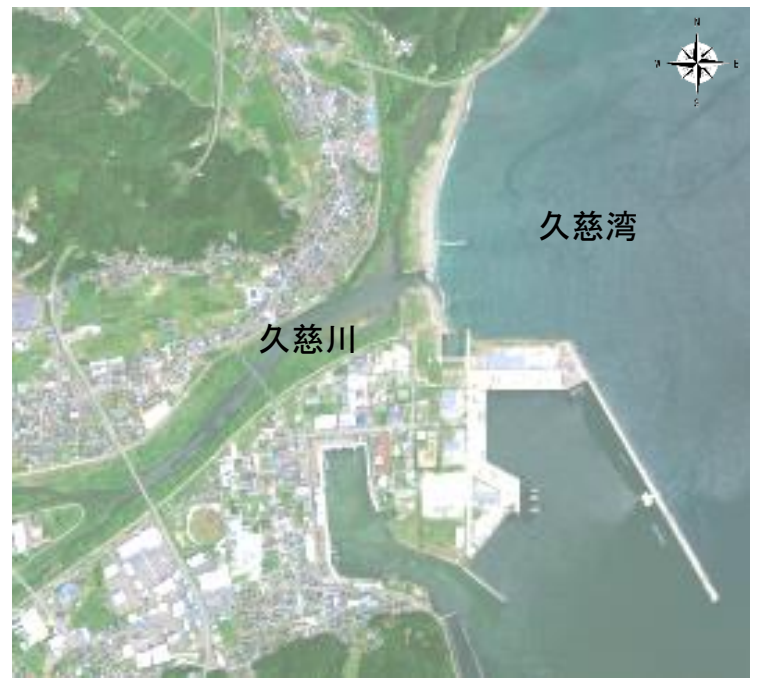

写真-1 東日本大震災以前の岩手県久慈市の様子

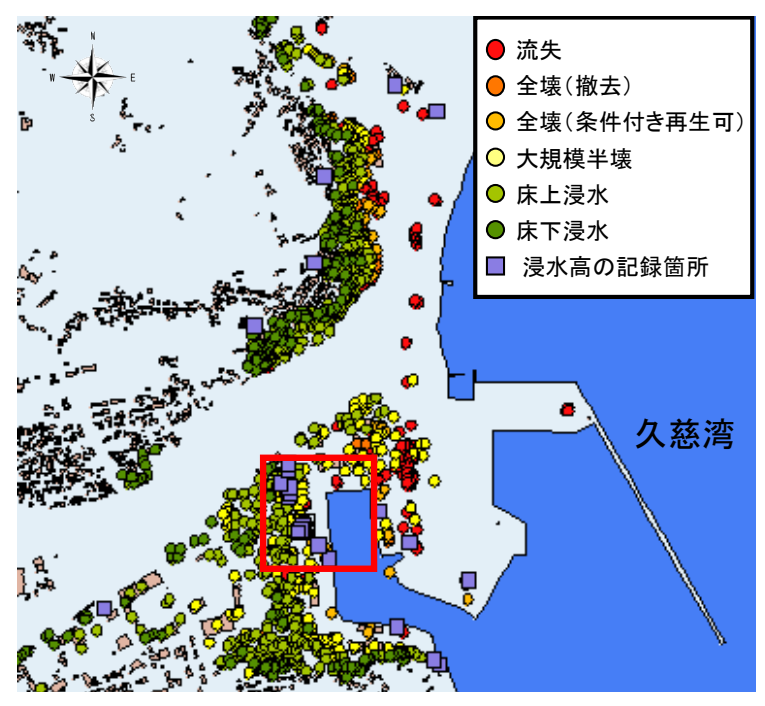

図-1 岩手県久慈市の建物被災分布

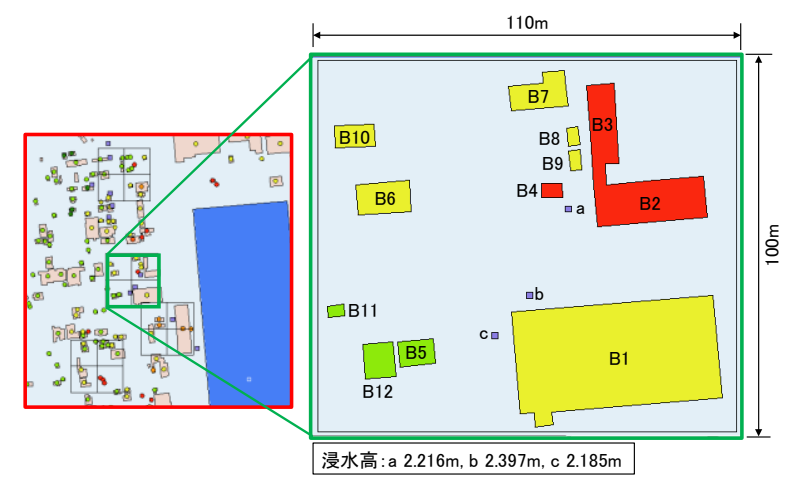

図-2 選定した街区における建物群

慈湾へと注ぎ，その両岸に平野部が形成されている．ま た，建物の被災分布は，図-1に示寸ように流失から床下 浸水までバラついていることから，久慈市を対象として， 上記の条件に適した街区の建物群を選定する。その結果,

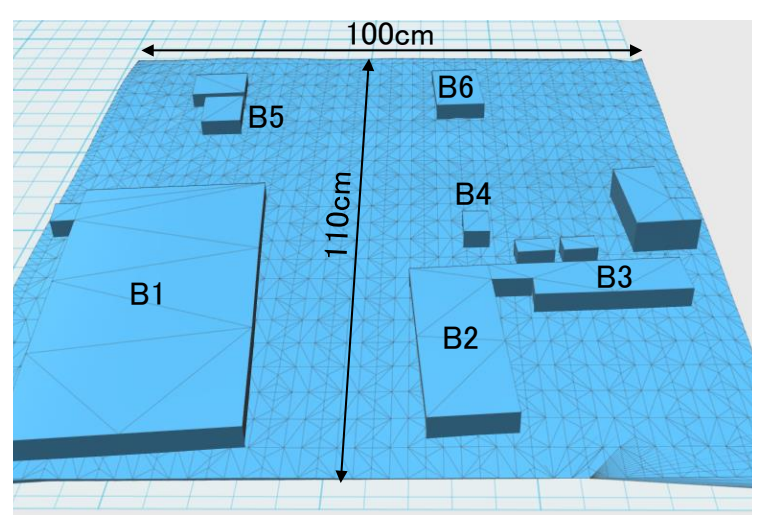

図-3 AutoCADによる街区の建物群の TINサーフェス

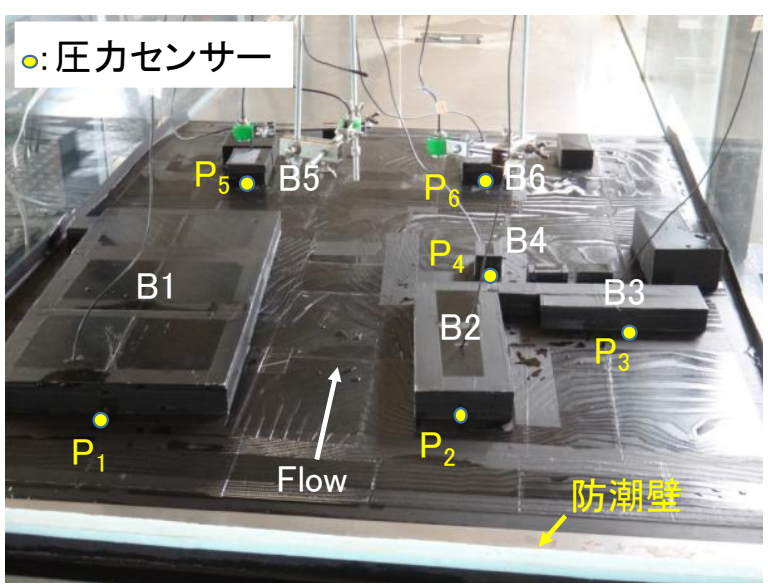

図-4 3Dプリンターで製作された模型の建物群

図-2に示寸複数の候補から緑線で囲まれた街区の建物群 を選定した．その街区内の建物総数は11戸であり，各建 物の被災規模は流失が2戸，大規模半壊が6戸，床上浸水 が3戸である．なお，図中の各建物の色は，図-1に示す 建物被災分布の凡例と対応している。.また，浸水高は3 地点で記録されており, 海側から $\mathrm{a}: 2.216 \mathrm{~m}, \mathrm{~b}: 2.397 \mathrm{~m}$

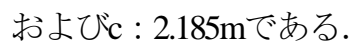

\section{(2) 建物群の模型製作}

選定した街区における建物群の模型製作は，次のa)か らc)までの過程で行われた.

a) ArcGIS Data Collectionプレミアシリーズ詳細地図（東 北版）を基に，ArcMap上で建物データをshpファイ ル形式に変換する.

b) AutoCADCivil3Dを用いて地形および建物を図-3に示 すようなソリッドモデルで表す．このとき，国土地 理院の基盤地図情報による標高データを基に，デー 夕間を線形補間し，TINサーフェスと呼ばれる不規 則に分割された三角形網で地形の凹凸を再現する. 


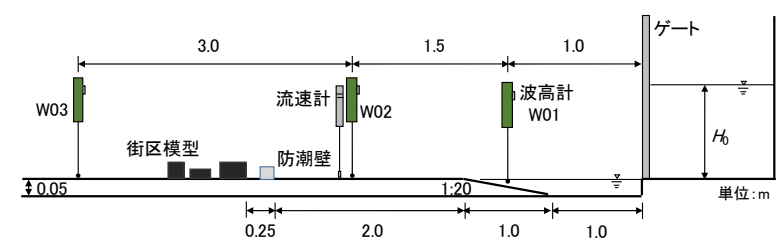

図-5 段波発生装置付開水路および計測機器の位置

表-1 各模型建物（B1～B12）における建床面積 $A_{b}$ よび 建物周囲長 $L_{b}$

\begin{tabular}{c|c|c|c|c|c}
\hline Bldg & $A_{b}\left[\mathrm{~cm}^{2}\right]$ & $L_{b}[\mathrm{~cm}]$ & Bldg & $A_{b}\left[\mathrm{~cm}^{2}\right]$ & $L_{b}[\mathrm{~cm}]$ \\
\hline B1 & 1520.4 & 171.4 & B7 & 118.8 & 49.9 \\
\cline { 1 - 4 } B2 & \multirow{2}{*}{503.6} & 143.2 & B8 & 15.4 & 16.1 \\
\cline { 1 - 3 } B3 & & B9 & 16.7 & 17.0 \\
\hline B4 & 21.6 & 18.7 & B10 & 63.0 & 33.1 \\
\hline B5 & 64.8 & 32.7 & B11 & 14.2 & 15.4 \\
\hline B6 & 119.7 & 45.4 & B12 & 77.4 & 32.7 \\
\hline
\end{tabular}

c) 123D Desing でソリッドモデルを3Dプリンター （MUTOH製，MF-1000）を用いて製作可能な大き さに分割し，図-4に示すような建物群の模型を製作 した.

模型の縮尺は，フルードの相似則を基に，1/100とし， 建物の高さは一階建てを $3.5 \mathrm{~cm}$ (B7以外) , 二階建て

（B7）を6.0 cmとした。また，街区の面積 $A$ は $1100 \mathrm{~cm}^{2}$ （長さ $100 \mathrm{~cm} \times$ 幅 $110 \mathrm{~cm} ）$ である. 表-1は，各模型建物 （B1〜 B12）の建床面積 $A_{b}$ および建物の周囲長 $L_{b}$ を示す. なお，建物B2とB3は合計值を表す。

\section{(3) 実験装置および方法}

実験は，図-5に示すように計測区間が長さ10m，高さ $0.8 \mathrm{~m}$ ，幅 $1.0 \mathrm{~m}$ の開水路を用いて実施した。 上流側に備え 付けられた貯水槽（長さ $2.35 \mathrm{~m}$, 高さ $1.4 \mathrm{~m}$, 幅 $1.0 \mathrm{~m}$ ) に 水を貯め, コンプレッサーによりゲートを急開放させる ことによって，段波状の津波汇濫流を発生させた，海域 の斜面勾配は $1 / 20$ ，初期の水深は $5.0 \mathrm{~cm}$ とた。氾濫流の 水位は，サーボ式波高計（ケネック製，SH30）を用い てゲートから $1.0 \mathrm{~m}$ (W01），2.5m（W02）および5.5m （W03）の位置で測定した. 流速は，プロペラ流速計 (ケネック製，VOT2-100-05N）を用いてゲートから $2.5 \mathrm{~m}$ （W02）の位置で計測した.

図-4に示した街区における建物群の模型は，その海側 がゲートから $4.25 \mathrm{~m}$ の位置に設置し，その前面に高さ $5 \mathrm{~cm}$ の防潮壁を設けた．B1〜B6の建物に圧力センサー（共 和電業, PS-05KD）を建物前面の下部（底面からセンサ 一中心が $1 \mathrm{~cm} の$ 位置) に埋め込み，汇濫流の圧力P1 P6

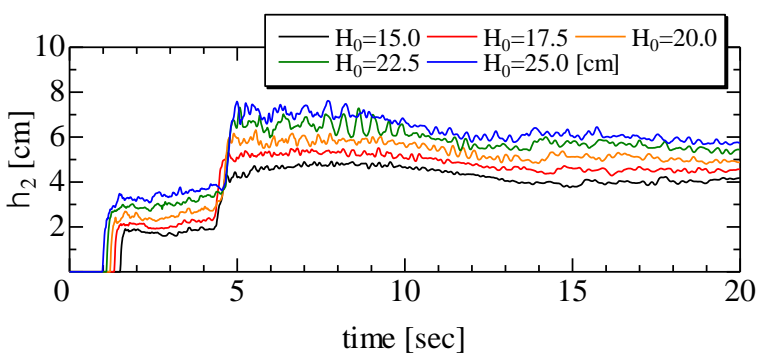

図-6 各貯水 $H_{0}$ におけるW02（ゲートから $2.5 \mathrm{~m} ）$ の位置で の水位 $\eta_{2}$ の時間変化

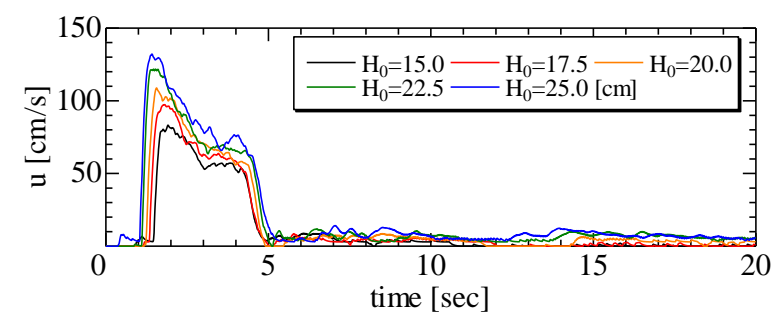

図-7 各貯水 $H_{0}$ におけるW02の位置での流速 $u$ の時間变化

表-2 各貯水位 $H_{0}$ におけるW02の位置での最大水位 $\eta_{2} m$, 最 大流速 $u_{m}$ おびフルード数 $F r$

\begin{tabular}{c|c|c|c}
\hline$H_{0}[\mathrm{~cm}]$ & $\eta_{2 m}[\mathrm{~cm}]$ & $u_{m}[\mathrm{~cm} / \mathrm{s}]$ & $F r$ \\
\hline 15.0 & 4.95 & 83.8 & 1.20 \\
\hline 17.5 & 5.54 & 97.3 & 1.32 \\
\hline 20.0 & 6.29 & 109.6 & 1.40 \\
\hline 22.5 & 7.30 & 123.9 & 1.46 \\
\hline 25.0 & 7.53 & 130.6 & 1.52 \\
\hline
\end{tabular}

を計測した。なお，建物B2とB3は一つの建物であるが， 別棟の建物と見なして，それぞれの圧力P2および 3 3を計 測した.

貯水槽の水位 $H_{0}$ は， $15.0,17.5,20.0,22.5,25.0 \mathrm{~cm} の 5$ 種類とし，それぞれ同水位で3回の計測を行った。計測 時間は，波高計W01を汇濫流が通過してから20秒間を記 録し, 各計測機器のサンプリング周波数は $100 \mathrm{~Hz}$ とた.

\section{(4) 実験条件}

図一および7は，各貯水位 $H_{0}$ でのW02（ゲートから $2.5 \mathrm{~m})$ の位置における水位 $\eta_{2}$ および流速 $u$ の時間変化を 示す. 図-6に示される各貯水位で発生させた段波の水位 $\eta_{2}$ は，貯水位の条件に依らず，段波先端の遡上に伴う一 段目の増加の後，防潮壁による反射波の影響を受けた二 段目の増加が見られる. そして, 貯水位の高さに比例し て水位は大きくなるが，何れも二段目の増加後の水位は しばらく持続し，時間経過と共に徐々に低下するように なる。 
図-7に示される流速 $u$ は，一段目の水位増加時に最大 流速に達し，二段目の水位増加時には，防潮壁に反射し た戻り流れの影響を受けてゼロに近づくようになる.

表-2は，貯水位 $H_{0}$ とW02での最大水位 $\eta_{2 \mathrm{~m}}$ および最大流 速 $u_{\mathrm{m}}$ を示寸. また, $\eta_{2 \mathrm{~m}}$ と $u_{\mathrm{m}}$ から求めたフルード数 $F r$ も併 せて示す．各貯水位での実験において，Frの值が2未満 になるような条件とした。

\section{3. 建物群に二作用する波圧特性}

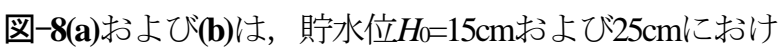
る各建物前面に作用寸る圧力（P1～P6） の時間変化を示 す. 図-8(a)の $H_{0}=15 \mathrm{~cm}$ 見ると，建物B1およびB2では, P1およびP2の圧力值から衝撃波圧がわずかに発生してい るが，建物B3〜B6では，明確な衝撃波圧は生じず持続 波圧が発生している. 図-8(b) $の H_{0}=25 \mathrm{~cm}$ を見ると，建物 B1およびB2では，明らかに衝撃波圧が生じていること が確認できる. 建物B3〜B6では，氾濫流が建物に衝突 するときに若干の変動が生じるが，明確な衝撃波圧は生 じていない，また，P1およびP2の最大圧力の2 割弱にま で減少していることがわかる。この要因として，建物 B1およびB2では，防潮壁と建物の間に防壁となるよう なものがないため, 汇濫流が建物前面に直接作用寸る. 一方，建物B4〜B6では，各建物の前方（海側）に存在 する建物が防壁となるため, 汇濫流の直接的な力の作用 を受けずに済む．さらに，建物B3では，前方に建物が 存在しないが，B1やB2の建物に比べて防潮壁から離れ ていることと，B2の建物が緩衝材の役目を果たしてい るものと考えられる.

また, $H_{0}=25 \mathrm{~cm} の$ 氾濫流が各建物に到達するまでの時 間に大きな差は見られないが， $H_{0}=15 \mathrm{~cm}$ では，B1やB2に 到達してからB5およびB6の建物に到達するまでに時間 差が生じている. 特に, B1やB2の背後近くにあるB4で も大きな時間差が生じていることがわかる．この要因と して, 入射波の高さが建物を上回るか否かに依存し，建 物より低い津波の場合，前面に面積の大きい建物がある ことによって, 背後の建物に津波が到達するまでに時間 を要するものと推察される.

次に, 各実験条件で得られた最大波圧 $p_{m}$ を表-2で示し た最大水位 $\eta_{2 m}$ の值を用いて無次元化した最大波圧とフ ルード数 $F r$ との関係を図-9に示寸，建物B1およびB2 と それ以外の建物B3〜B6の無次元最大波圧を比較すると， $F r の$ 值が1.3程度まで有意な差が現れない．しかしなが ら，その值が1.4を越えるようになると，大きな差が現 れるようになり，建物B1およびB2では，指数関数的に 増加する，それに対し，B3〜B6の建物では，著しい増 加は見られない，特に，建物B5およびB6では，フルー ド数に依らず，ほとんど変化しないことがわかる。

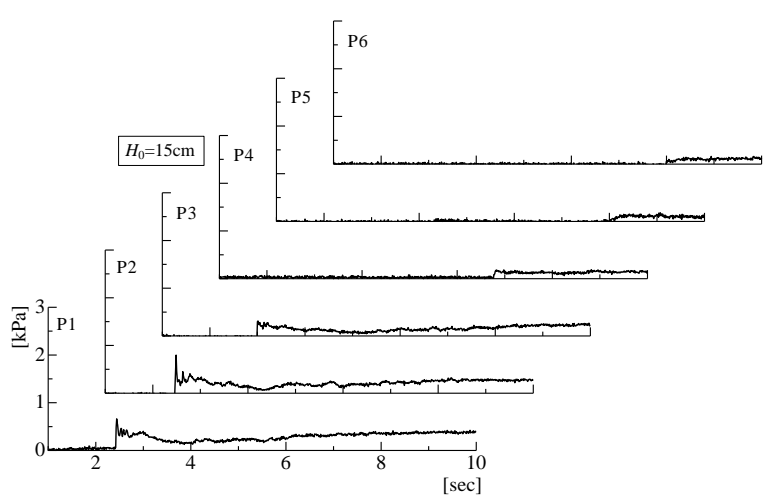

(a) 貯水位 $H_{0}=15 \mathrm{~cm}$

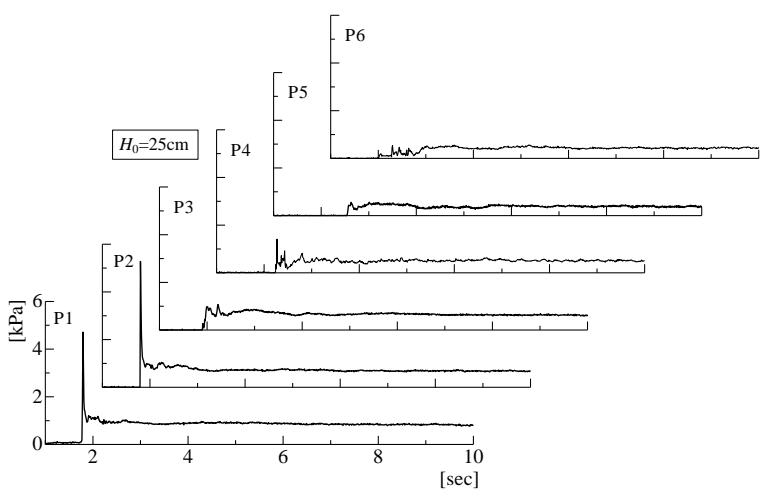

(b) 貯水位 $H_{0}=25 \mathrm{~cm}$

図-8 建物B1からB6までの各建物前面に作用寸る圧力（P1 〜P6）の時間変化

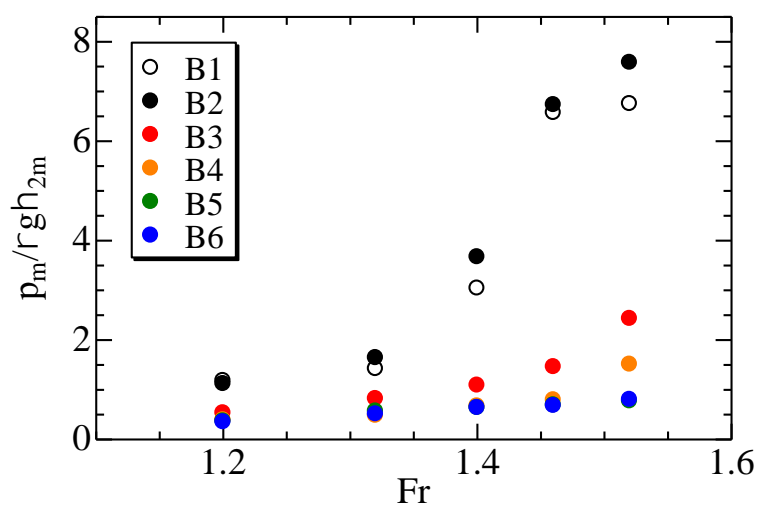

図-9 フルード数 $F r$ と各建物の無次元最大波圧との関係

以上より，建物群として個々の建物に作用する津波の 波圧を捉えた場合, その力を直接受ける建物に比べて, 後方に存在する建物に作用する力は, 著しく減少するこ とが明白である.

\section{4. 建物群の津波耐力評価}

ここでは，街区における各建物の必要津波耐力の評価 方法について, 建物群を面として捉え, 着目建物の前方 の建物面積またはその形状を指標とした検討を行う。 


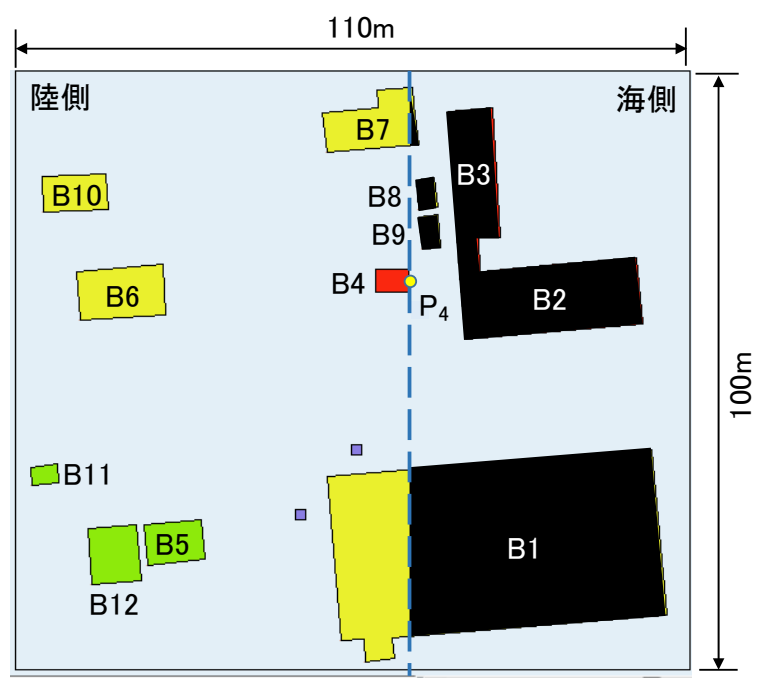

図-10 建物面積率の算出方法（建物B4に着目した場合）

\section{(1) 建物面積率による耐力評価}

建物群に作用する津波氾濫流の波圧は，着目する建物 に関連した建床面積に依存すると見なし，街区面積に占 める建物の面積率で津波耐力評価を行う。具体的な面積 率の求め方として，例えば図-10に示すように着目する 建物がB4の場合，その建物前面（図中の破線）より前 方（海側）に存在する建物の総建床面積A。（図中の黒色 部分）を求め, 街区面積 $A$ に占める建物面積率 $A_{o} / A$ を算 出する。

図-11は，B1からB6までの各建物面積率 $A_{0} / A$ と無次元 最大波圧との関係を示寸．建物面積率 $A_{0} / A$ の值は，当然 ながら陸側の建物になる程大きくなり，建物に作用する 波圧に違いが生じるようになる。建物B1およびB2では, 入射する津波の規模に依存した波圧の力を受けるが，前 方に建物が存在する建物B3〜B6では，入射波の規模に よる差が徐々に小さくなることがわかる，さらに，各建 物面積率における無次元最大波圧を包括寸るように回帰 式を求めると, 次式のような指数関数として表すことが できる.

$$
\frac{p_{m}}{\rho g h_{2 m}}=8.3 \exp \left(-1.1 \frac{A_{o}}{A}\right)
$$

ここで， $\rho$ は水の密度，gは重力加速度である.

\section{(2) 建物円形度による耐力評価}

次に, 建物群としての面的な形状の複雑さを考慮して 津波耐力評価を検討する. 図形の複雑さを表すための数 值として，円形度があるが，その円形度を用いて次のよ うな建物円形度 $C_{b}$ を定義する。

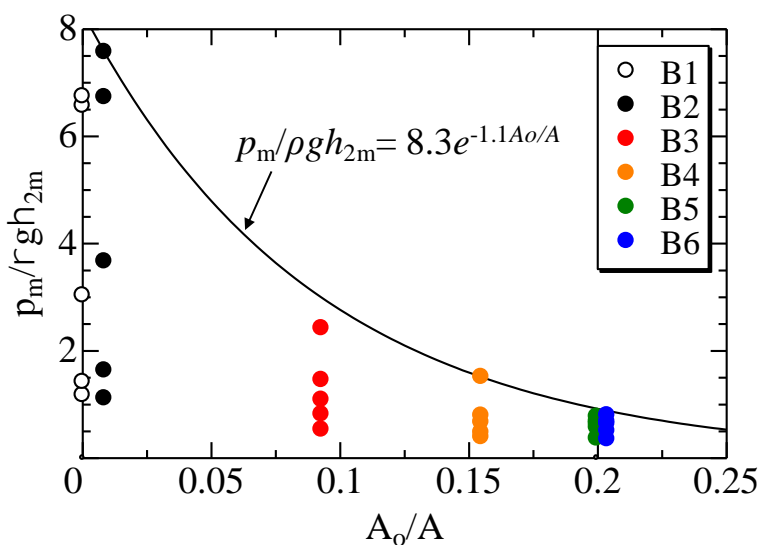

図-11 建物面積率 $A_{o} / A$ と各建物の無次元最大波圧の関係

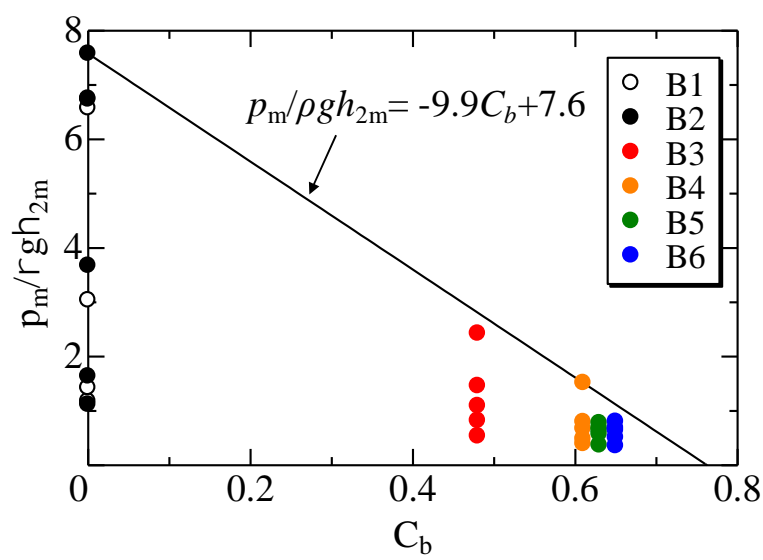

図-12 建物円形度 $C_{b}$ と各建物の無次元最大波圧の関係

$$
C_{b}=\frac{4 \pi \sum_{i=1}^{n} A_{o i}}{\sum_{i=1}^{n} L_{b i}^{2}}
$$

ここで，AoiおよびLbiは，着目建物より前方にある建物 の面積および建物周囲長の総和であり，nは建物の戸数 を意味する．なお，建物B1とB2の $C_{b}$ の值は，前面に建 物がないことからゼロとした。

図-12は，B1からB6までの各建物円形度 $C_{b}$ と無次元最 大波圧との関係を示す. 前方に建物の占める割合が多く なる建物において $C_{b}$ の值が大きくなり，その值の増加に 伴い無次元最大波圧が減少するような傾向を示す。さら に，建物面積と同様に，建物円形度による包絡線は，一 次関数として, 次式のように表すことができる.

$$
\frac{p_{m}}{\rho g h_{2 m}}=-9.9 C_{b}+7.6
$$


図-2に示した建物被災分布では，B5，B11およびB12 の建物は床上浸水であることを踏まえると，建物面積率 が $A_{o} / A>0.2$ または建物円形度が $C_{b}>0.65$ の条件であれば, 建物が倒壊する危険性が低くなると考えられる。しかし ながら，B6の建物における両指標の值は，B5より大き な值であるにも関わらず，被災状況は大規模半壊である。 被災規模が大きくなった原因として，B5の前方にある B1の被災状況が大規模半壊であるのに対し，B6の前方 にあるB2，B3およびB4が全壊であるため，これらの破 壊された建物が漂流物となり，後方の建物に 2 次的な被 害を及ぼしたことに依るものと推察される.

また，両指標と無次元最大波圧の関係を比較すると， 建物円形度は，建物面積率に比べて建物の位置による違 いが余り生じないことがわかる．特に，B4，B5および B6の建物位置および前方建物の存在がそれぞれ異なる にも関わらず，その差が小さことから， $C_{b}$ の值は，着目 建物よりも前方（海側）に存在する建物形状の複雑さを 十分に評価できているとは言えず，改善の必要性がある と考えられる.

\section{5. 結論}

街区を想定した建物群における各建物に作用する津波 汇濫流の波圧特性を検討するため，3Dプリンターを用 いて精巧に再現した模型実験を行った，その結果，以下 の主要な結論を得た。

（1） 前方（海側）に建物が存在することによって，後 方の建物に作用する波圧は，著しく減少すること が明らかになった。

（2）後方の建物に作用する波圧は，入射波の増大に関 わらず，小さくなることがわかった。

（3）前方の建物の高さより低い津波の場合，背後の建
物一の津波到達時間が遅くなることがわかつた。

（4）建物の津波耐力評価として，建物面積率および建 物円形度の指標を提案し，建物倒壊の危険性を判 断するための指標になり得ることを示唆した.

今後の課題として，建物円形度の指標において，建物 の複雑さを十分に表現できているとは言えない. また, 建物面積においても，地形勾配や海岸からの距離を踏ま えた改良が必要であると考えられる。

謝辞：本研究は，科研費(基盤(C))26350473の助成を受け た成果である.ここに記して謝意を表します。

\section{参考文献}

1） 国土交通省都市局（2011）：東日本大震災からの津 波被災市街地復興手法検討調査のとりまとめについ

て http://www.mlit.go.jp/toshi/toshi-hukkou-arkaibu.html, 参照 2016-1-22.

2) 小笠原敏記, 古坂梢, 柳川竜一, 岩間俊二, 堺茂 樹：東北地方太平洋沖地震津波による岩手県沿岸に おける建物被害の特性, 土木学会論文集 B2（海岸工 学), Vol.69, No.2, pp.I_356-I_360, 2013.

3) Asakura,R., K.Iwase, T.Ikeya, M.Takao, T.Kaneto, N.Fuji and M.Ohmori : The tsunami wave force actiong on land structure, Proc. of $28^{\text {th }}$ Int. Conf. on Coastal Engineering, ASCE, pp.1191-1202, 2992.

4) 有光剛, 大江一也, 川崎浩司: 構造物前面の浸水深 と流速を用いた津波波圧の評価手法に関する水理実 験，土木学会論文集 B2 (海岸工学)，Vol.68，No.2， pp.I_776-I_780, 2012 .

5) 有川太郎, 大塚隆行：防潮堤背後の建物に作用寸る 津波力に関する実験的検討，土木学会論文集 B2（海 岸工学) , Vol.70, No.2, pp.I_806-I_810, 2014.

6) 東北地方太平洋沖地震津波合同調査グループ, http://www.coastal.jp/ttjt/, 参照 2012-12-29.

(2016.3.16 受付)

\title{
EVALUATION METHODS FOR TSUNAMI FORCE ACTING ON BUILDING GROUP IN MODEL EXPERIMENT
}

\author{
Toshinori OGASAWARA, Yutaka MITSUHASHI, Kohta MUROI and Tatsuya \\ MIZUNO
}

In the Great East Japan Earthquake, it was confirmed that the damage scales of immediate buildings within a block are different respectively. The evaluation method for tsunami force acting on the building group in the block will be required. To clarify the tsunami force for the buildings, the model experiments were performed using the model building group in the block reproduced by $3 \mathrm{D}$ printer. The method for evaluation of tsunami force acting on the buildings are investigated using the area and the shape of the building group.

As a result, the tsunami force acting on the buildings in the back of the building of sea side has decreased markedly. The forces for the rear buildings also become small and uniform, regardless of the conditions of incident wave. Furthermore, it is proposed that the parameters used the area ratio and the circularity of the building group are new means for evaluation of tsunami force. 